\title{
Exhaust Gas Treatment in Thermal Power Plants: A Review
}

\author{
Faralu Muhammad Sani*1 and Olatunde Ajani Oyelaran ${ }^{2}$ \\ Research Scholar ${ }^{1}$ and Research Scholar ${ }^{2}$ \\ ${ }^{1-2}$ Department of Mechanical Engineering \\ ${ }^{1}$ Usmanu Danfodio University Sokoto P.M.B. 2346, Sokoto \\ ${ }^{2}$ Federal University Oye-Ekiti P.M.B. 373, Oye-Ekiti \\ Nigeria
}

\begin{abstract}
An extensive review of exhaust gas treatment in thermal power plants was conducted. The nature of emissions and hazards caused by pollutants at electric thermal plants were clearly indicated. CO2 capture, desulfurization, denitrification and PM collection as control measures for treatment were successfully well explored and recommended to be best in practice. The majority of the studies under consideration are consistent with their findings and agree with standard procedures. The work can serve as a platform to find benefits in pollution reduction in the atmosphere which mitigates global warming and prevent deadly respiratory diseases. However, more effort is needed to improve the baghouse PM collection system and the eventual method of disposal.
\end{abstract}

Key Words: Desulfurization, Denitrofication, Exhaust Gas, Thermal Power Plant, Pollutants.

\section{INTRODUCTION}

In modern day life energy is basically very essential in all aspects. It is very crucial for industrial production and the fuel for transportation as well as for the generation of electricity in thermal power plants. Sustainable human development is heavily dependent on energy to drive comfortable and meaningful human existence. In this modern time electricity has globally been identified as a necessary tool for barely all human activities. Global exponential rise in population is closely linked to increasing energy demand and requirements for environmental protection. This necessitates and requires the use of advanced methods to treat exhaust gases at electricity generating plant [1-3]. There are no much reviews on the subject and hence the need to extensively study and report the trend of research and way forward in this very important field.

Fossil fuels in their various forms have been the main sources of electricity for many years. Liquid and gaseous fuels are more efficient than their traditional solid phase counter parts. Yet, by 1980's about 800 million tons of coal was being consumed each year in the United States of America. Electric generating utilities accounted for approximately $85 \%$ of the said figure which translated to about 680 million tons of coal [4]. Coal is the most abundant and widely distributed fossil fuel globally, with reserves for all types estimated to be at about 990 billion tonnes, enough for 150 years at current consumption. Coal fuels $42 \%$ of global electricity production, and is likely to remain a key component of the fuel mix for power generation to meet increasing electricity demand [5]. Natural gas (NG) has emerged as an important fuel source for power generation. Combined cycle power plant technology using liquefied natural gas (LNG) is not only readily available but is also proving to be attractive for quick capacity additions and at the same time is capable of meeting cost and environmental goals. Its application is increasing because of its inherent advantages in terms of low capital costs and low emission. The most efficient units achieve availability of $95 \%$ and $52 \%$ net efficiency.

The combustion of fossil fuel to generate power pollutes the air with many materials, such as: particulate matter (PM), toxic mercury; acidic gases such as $\mathrm{SO}_{x}, \mathrm{NO}_{x}, \mathrm{HCl}$, etc.; greenhouse gases like carbon dioxide $\left(\mathrm{CO}_{2}\right)$, other $\mathrm{CO}_{x}, \mathrm{~N}_{x} \mathrm{O}_{y}$, etc. These emissions constitute a potential threat to the environment and its inhabitants. The adverse effects of air pollution are easily seen in the consequences of climate change. Air pollution poses serious health hazards that can result in increased mortality rate due to chronic bronchitis and other deadly respiratory diseases caused by poor quality air. Emission of greenhouse gases $\left(\mathrm{CO}_{2}\right.$ and $\left.\mathrm{N}_{2} \mathrm{O}\right)$ also aggravates the problem of global warming. These emissions also increase the tendency of acid rain [6], a situation that results in destruction of forest and aquatic life as well as building decay. It becomes clear that emissions from thermal power plants will certainly have huge economic consequences. These and other factors necessitate preventive measures to be taken. The aim of this research is to make a review of exhaust gas treatment technology for thermal power plants. This review will find and summarize 
typical solutions to the problems of air pollution caused by combustion of fossil fuels in thermal power plants, thereby giving preventive measures to deadly respiratory diseases. It is also important that the research will create awareness for the need of pollution control in places that are preparing to establish thermal power plants for energy generation.

\section{Thermal Power Plant}

A power station is also referred to as a generating station, power plant, or powerhouse. It is an industrial facility for the generation of electric power. The greatest variation in the design of thermal power stations is due to the different energy sources. Most thermal power stations use fossil fuel. Singh et al. [7] reported that a coal-fired power plant burns coal to produce electricity. In a typical coal-fired plant, there are pulverisers to mill the coal to a fine powder for burning in a combustion chamber of the boiler. The heat produced from the burning of the coal generates steam at high temperature and pressure. The high-pressure steam from the boiler impinges on a number of sets of blades in the turbine. This produces mechanical shaft rotation resulting in electricity generation in the alternator. The exhaust steam from the turbine is then condensed and pumped back into the boiler to repeat the cycle. This description is very basic, and in practice, the cycle is much more complex and incorporates many refinements. It was also reported in [8] that conventional steam producing thermal power stations generate electricity through a series of energy conversion stages: firstly fuel is burnt in boilers to convert water into high pressure steam, which is then used to drive a turbine to generate electricity. In coal fired power stations the coal is pulverised to enhance combustion efficiency, then fed into the combustion chamber of a boiler and burned. Electricity is generated from oil using similar methods. The work further highlighted that combined cycle power stations burn fuel in a combustion chamber and the exhaust gases are used to drive the turbine. Waste heat boilers capture energy from the exhaust gases for the production of steam, which is then used to drive another turbine; this process is generally more efficient than conventional systems. Advanced coal utilization technology (e.g. fluidized bed combustion) tends to be more efficient than conventional and combined cycle systems. Reference [8] further reported that Gasification Combined Cycle (IGCC) power plant is the most environmentally friendly coal-fired power generation technology. IGCC uses a combined cycle format with a gas turbine driven by the combusted gas from coal combustion or high energy waste gases from refineries, while the exhaust gases are heat exchanged with water/steam to generate superheated steam to drive a turbine.

\subsection{Emission Characteristics of Thermal Power Plants}

Flue gas from combustion of fossil fuels contains carbon dioxide and water vapour, as well as other substances such as nitrogen, nitrous oxides, sulfur oxides, and in the case of coal-fired plants, fly ash (PM) and mercury [4]. The study indicated that emissions from combustion of coal consist of: $\mathrm{SO}_{2}, \mathrm{NO}_{2}$ (sulphur and nitrous oxides) gases that are acidic in nature as well as water vapour; particulate matter with sizes in microns and toxic mercury; and the greenhouse gases $\left(\mathrm{CO}, \mathrm{CO} 2\right.$ and $\left.\mathrm{N}_{2} \mathrm{O}\right)$. These emissions will depend on the type of coal, its calorific value and source, as well as the quantity burnt. Singh et al. [7] indicated that the burning of coal in the boiler of a power plant produces flue gas. The main constituents of the flue gas are nitrogen $\left(\mathrm{N}_{2}\right)$, $\mathrm{CO}_{2}$ and water $\left(\mathrm{H}_{2} \mathrm{O}\right)$. It carries PM and other pollutants. There are traces of some oxides such as oxides of sulphur (SOx) and oxides of nitrogen (NOx) depending on the combustion technology and fuel used.

\subsection{Environmental Impact of Thermal Power Plant}

Najjar [9] reported $\mathrm{SO}_{2}$ to be an air pollutant with main source at electric power plants that burn high-sulfur coal. The study suggested that regulations should be forced for plants to install $\mathrm{SO}_{2}$ scrubbers, to switch to low-sulfur coal, or to gasify the coal and recover the sulfur. Sulfur oxides and nitric oxides react with water vapour and other chemicals high in the atmosphere in the presence of sunlight to form sulfuric and nitric acids. The acids formed usually dissolve in the suspended water droplets in clouds or fog. These acid-laden droplets, which can be as acidic as lemon juice, are washed from the air on to the soil by rain or snow. This is known as acid rain. Pickering \& Owen in [10] indicated that acid rain or acid deposition leads to acidification of groundwater, surface water, damage to life (particularly forests and aquatic) and building decay. The work attested that acid rain is also caused by the reaction of nitrous and sulphur oxides with water in the atmosphere. Gottlieb et al. [11] reported that coal ash is the waste product left over after coal is combusted, or burned. The work highlighted how toxic coal ash is, its generation and grossly mismanaged disposal. The work confirmed an incidence in the U. S., in 2008 where an earthen wall holding back a huge coal ash disposal pond failed at the coal-fired power plant in Kingston, Tennessee. The 40-acre pond spilled more than 1billion gallons of coal ash slurry into the adjacent river valley, covering some 300 acres with thick, toxic sludge, destroying three homes, damaging many others and contaminating the Emory and Clinch Rivers. The report also indicated that when the U.S. Environmental Protection Agency tested water samples after the spill, they found toxic heavy metals that included arsenic, which they measured at 149 times the allowable standard for drinking water. Elevated levels of other toxic metals which included: lead, thallium, barium, cadmium, chromium, mercury, and nickel were as well detected. The report indicated that despite that catastrophic spill in Tennessee, the full dimensions of the health threats from coal ash were just beginning to register with the American public. The real danger with fly-ash emission was indicated by Howard et al. [12] where it was reported that exposure 
to ambient particulate matter caused an estimated 4.2 million deaths worldwide in 2015 . Amongst all the common air pollutants Liu et al. [13] reported that PM2.5 is the largest contributor to global mortality and morbidity.

Reference [14] reported that PM from exhaust gases is considered detrimental to human health as it penetrates down into the human lung. Large particles are of less concern because they are effectively removed by the pulmonary system. As fine particulates can easily be transported by air currents, their detrimental effects can be encountered at far distance from the exhaust plume. Apart from health hazard particulate matter in form of smoke has negative impact on human vision.

\section{An Overview of Exhaust Gas Treatment in Thermal Power Plants}

\subsection{Treatment of Carbon Dioxide at Thermal Power Plant}

Liu et al. [13], Marion et. al. [15], and Vinod \& Reddy in [16] agreed that there are large variations in $\mathrm{CO}_{2}$ emissions per MW of electricity generated by fossil fuels due to differences in generation efficiency, fuel selection, and plant age. Low-carbon fuels such as natural gas and improvements in energy conversion efficiency have been steadily declining the average $\mathrm{CO}_{2}$ emissions per MW. In the process of post combustion capture of $\mathrm{CO}_{2}$, the gas is separated from flue gases after combustion has taken place. Sequestration of $\mathrm{CO}_{2}$ from power plants only comes to effect after the gas is captured in its relatively pure form. Sequestration of $\mathrm{CO}_{2}$ entails the storage or utilization of $\mathrm{CO}_{2}$ in such a way that it is kept out of the atmosphere. Small proportion of captured $\mathrm{CO}_{2}$ could be utilized to make chemicals whereas its large quantities can enhance oil and natural gas production. Storage of $\mathrm{CO}_{2}$ could be accomplished in a number of ways including underground storage or in ocean sequestration. Absorption by use of amines, different adsorption techniques, use of membranes, etc is among the several methods for $\mathrm{CO}_{2}$ removal from a gas stream. In the process of capture 85 to $95 \%$ of $\mathrm{CO}_{2}$ in the fuel can be recovered. $\mathrm{CO}_{2}$ can also be captured by utilizing solid chemicals that react with the gas in solid form. These $\mathrm{CO}_{2}$ capture processes have significant energy requirements, which reduce the power generation efficiency by up to $40 \%$ and net power output up to $40 \%$. Post-combustion $\mathrm{CO}_{2}$ capture is commonly believed to be one of the major strategic means to reduce the $\mathrm{CO}_{2}$ emission in coal power plants $[13,15,16]$.

Vinod \& Reddy [16] further reported two other processes of carbon capture thus: Pre-combustion capture technique that reacts the fuel with oxygen or air, and possibly also with steam, to produce a synthesis gas that composed mainly of carbon monoxide and hydrogen. The carbon monoxide is then reacted with steam in a catalytic reactor to give $\mathrm{CO}_{2}$ and more hydrogen. The $\mathrm{CO}_{2}$ is then separated by a physical or chemical absorption process resulting in a hydrogen-rich fuel which can be used in many applications, such as boilers, furnaces, gas turbines, engines and fuel cells. Pre-combustion capture of $\mathrm{CO}_{2}$ has to be part of the IGCC and will be the future of fossil fuel power. In oxy-fuel combustion technique, nearly pure oxygen is used for combustion instead of air, resulting in a flue gas that is mainly $\mathrm{CO}_{2}$ and $\mathrm{H}_{2} \mathrm{O}$. This simplifies the separation process as the water vapour can readily be condensed to liquid, leaving the $\mathrm{CO}_{2}$ for subsequent treatment. The study observed that post-combustion and oxy-fuel combustion can be retrofitted to today's coal plants. Both technologies are feasible, safe and have the potential to be cost-effective. The challenge lies in developing the processes so that they can be deployed economically on a large scale. Madejski [17] also highlighted a current big challenge that needs to assess the possibilities of $\mathrm{CO}_{2}$ capture and develops a technology that limits the emission of the greenhouse gas.

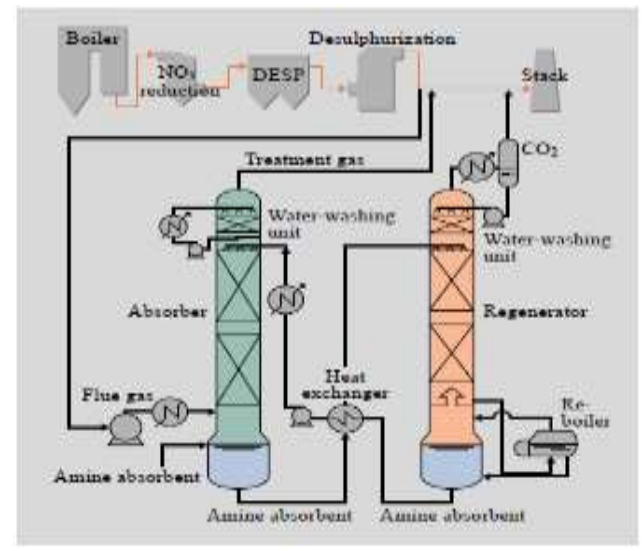

Figure 1: Process Flow of $\mathrm{CO}_{2}$ Recovery (Adopted from [21])

Samanta \& Ghosh in [22] theoretically analyzed partial repowering of a $250 \mathrm{MW}$ coal fired power plant. Some amount of pulverized coal was proposed to be combusted in a pressurized combustion chamber (PPCC). The product gas was thereafter to be expanded in a gas turbine and the exhaust fed to a boiler. The partial repowering predicted about $26.5 \%$ reduction in the specific $\mathrm{CO}_{2}$ emission of the plant. Mborah \& Agbomadzi in [18] proposed a method for the removal of carbon dioxide gas from the exhaust gases generated at Takoradi Thermal Power Station in Ghana with the aim of reducing the plant's carbon dioxide 
emission into the atmosphere. The method is a modification of the Fluor Daniel ECONAMINE FG process that eliminated the recycling of exhaust gas. This method removes carbon dioxide from exhaust gas by using an amine solution which comes into contact with exhaust gas in a counter-current manner. The work further reported that the method has been applied by 23 companies which produce $\mathrm{CO}_{2}$ on a large scale and recommended a cost feasibility study for its application at the Takoradi plant. From another perspective Martínez et al. [19] analysed a Ca looping system that used $\mathrm{CaO}$ as re-generable sorbent to capture $\mathrm{CO}_{2}$ from the flue gases generated in power plants.

\subsection{Treatment of SOx and NOx at Thermal Power Plant}

Environmental concern regulates many coal-fired power stations around the globe to install denitrification plants (DeNOx) for control of nitrogen oxide (NOx) and desulphurization plants (DeSOx) for sulfur oxide (SOx) removal from the flue gases. The Wet Flue Gas Desulfurization (WFGD) method is the most common technology for SOx control. The primary measures used inside the combustion chamber for NOx reduction yield only about 35\% efficiency. This is not enough to meet many environmental regulations. Selective Non-Catalytic Reduction (SNCR) and Selective Catalytic Reduction (SCR) are secondary measures of NOx removal. These techniques are more promising and located behind the boiler combustion zone. The secondary measures can reach about 50 and 95\% efficiencies for SNCR and SCR respectively [7, 17, 20]. Singh et al. [7] further identified that the properties of coal used in a boiler and environmental management policy of a plant are two major factors that determine the nature of flue gas treatment process. In some countries coal-fired power plants need to install DeNOx and DeSOx. Whereas the situation might be different with other countries as the study further elaborated that the coal used in Australia has very low sulphur content and therefore, the concentration of SOx from the burning of coal in Australia is relatively low. This factor warranted the absence of stringent regulatory requirements. Therefore, Australian coal plants in the past had not been required to have DeNOx or DeSOx units for clean up or treatment of NOx and SOx in the flue gas streams.

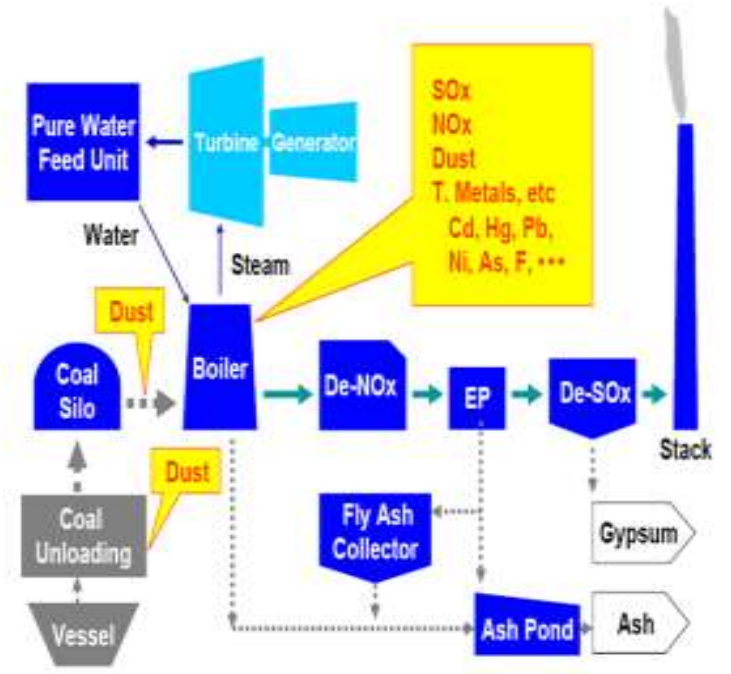

Figure 2: Pollutants and Pollution Control in Coal-Fired Power Plant (Adopted from [23])

Kikkawa et al. [21] reported that Babcock-Hitachi K.K. Company was developing a technology for reducing the amount of NOx, SOx, and other pollutants that are generated when coal is burned in thermal power plants to minimum levels. The work further indicated that Hitachi K.K. has developed and commercialized flue gas treatment technology for highly efficient elimination of NOx and SOx from flue gas. Furthermore, the company had developed a system for absorbing and recovering $\mathrm{CO}_{2}$ from flue gas by means of a unique amino solvent. The report finally concluded that Babcock-Hitachi K.K. and Tokyo Electric Power Company confirmed that the system was installed at a pilot plant using flue gas from Yokosuka Thermal Power Station and attained high $\mathrm{CO}_{2}$ elimination performance.

Kuroki et al [24] investigated the removal of air pollutants containing nanoparticles with a wet-type plasma reactor. A simulated exhaust gas was prepared for the study to evaluate performance using polystyrene latex particles having diameters of 29, 48, 100, 202, and $309 \mathrm{~nm}$, and $\mathrm{NO} / \mathrm{SO}_{2}$ gas cylinders. Removal efficiencies of more than $99 \%$ and $77 \%$ were obtained for $\mathrm{SO}_{2}$ and NOx, respectively. These results confirmed the wet-type pulsed corona discharge plasma reactor to be useful for the simultaneous removal of nano-particles, NOx, and SOx. High NOx removal efficiency of up to 74\% in atmospheric pressure nonthermal plasma reactor for NOx pollution control was also demonstrated by Morgan et al. [25]. The development and extended application of such reactors will make the task of exhaust gas treatment easier.

\subsection{Treatment of Particulate Matter at Thermal Power Plant}


The emission of particulate matter that results from the exhaust at power plants is controlled with such devices as: cyclone separators, bag house, and electrostatic precipitator (ESP). Cyclone separators are employed for coarse particle removal, whereas electrostatic precipitators are used for lower spectrum coarse particles as well as fine particle. ESP is one of the most widely used devise for controlling particulate matter especially fly ash. The efficiency of ESP depends upon the resistivity of particles which can be altered substantially to desired requirements by conditioning flue gases with some known chemicals. However, bag house is best suited for the control of fine particles and even up to partial removal of ultra fine particles [26, 27]. Much attention is being devoted to the study of formation and emission control of particulate matter. PM10 is one of the principal atmospheric pollutants generated from coal combustion in China. Yi et al. [30] investigated particulate emission control devices (PECDs), their classification and collection efficiencies. The study experimentally determined particulate matter emission efficiencies and size distribution at the inlets and outlets of PECDs at four different coal-fired power plants using anthracite and bituminous coals. Mass concentrations of PM1, PM2.5 and PM10 were determined in the range $0.03 \mu \mathrm{m}-10 \mu \mathrm{m}$ in aerodynamic diameter. The study determined collection efficiencies of electrostatic precipitator to be $99.0-99.89 \%$ and $98.2 \%-99.62 \%$ for PM and PM10 respectively. Alternatively bag-house collection efficiencies for PM and PM10 were 99.94\% and 99.76\%. However, the study attested that lower collection efficiencies were obtained for ESP and bag-house involving particle size range of $0.1 \sim 1 \mu \mathrm{m}$ as 90.8 $98.6 \%$ and $99.54 \%$ respectively.

Table 1: Total Collection Efficiencies of Different PM Sizes (Adopted from [28])

\begin{tabular}{ccccc}
\hline DP & PM1 & PM2.5 & PM10 & PM \\
\hline Power plant 1 - ESP & 90.83 & 95.58 & 98.20 & 99.00 \\
Power plant 2 - ESP & 98.59 & 99.16 & 99.62 & 99.89 \\
Power plant 3 - ESP & 95.74 & 96.75 & 98.58 & 99.76 \\
Power plant 4 - Bag-house & 99.54 & 99.72 & 99.76 & 99.94 \\
\hline
\end{tabular}

Wang et al. [29] estimated the influence of removal technology of particulate matter on total emissions in China and suggested that substituting ESPs with hybrid ESP/BAGs could reduce the total emissions to 104.3 thousand tons, with 47.48 thousand tons of PM2.5. The study investigated the influence of precipitators and wet flue gas desulfurization equipment on characteristics of PM2.5 emission from three coal-fired power stations. Higher removal efficiencies to those obtained by other types of precipitators, reaching up to $99 \%$ for PM2.5, were determined for hybrid ESP/BAGs. The work noted the efficiency of hybrid ESP/BAGs decreased by $1.9 \%$ when the first electrostatic field was shut down. The influence of hybrid ESP/BAG operating conditions on the performance of dust removal was also explored by the study. Bandyopadhyay and Mandal in [30] on the other hand studied the operation of wet electrostatic precipitators (WESP) as air pollution control device in an Indian coal fired thermal power plant to capture P.M. The WESP was installed for reducing the PM emission to meet the Indian stack emission standard of PM. Investigations interestingly revealed that the WESP reduced the $\mathrm{SO}_{2}$ and $\mathrm{CO}_{2}$ emissions potentially. The study suggested that operating a WESP for cleaning flue gas of a coal fired thermal power plant can be considered as a GHG emission mitigation option as well. However, the work noted that level of NOx emission could not be conclusively analyzed due to air dilution of the flue gas. Finally, it was suggested that the plant operators use dilute alkaline reagent to replace the water as the scrubbing medium so as to obtain multiple benefits of cleaning all acidic gases by the WESP having achieved better ash treatment. An interesting study by Howard et al. [12] compared the health benefits with the control costs of tightening PM emission standards for coal-fired power plants in Northeast Brazil to explore if current levels of emission standards are sufficiently stringent in a simple costbenefit framework. The study established through modelling that tightening existing PM10 emission standards yields health benefits that are over 60 times greater than emissions control costs in all the scenarios considered. The monetary value of avoided hospital admissions alone was at least four times as large as the corresponding control costs. The work suggested that these results provide strong arguments for considering tightening PM emission standards for coal-fired power plants worldwide.

\section{CONCLUTION}

An extensive review of exhaust gas treatment in thermal power plants was successfully carried out. The nature of emissions and hazards caused by these pollutants were clearly indicated. Control of these emissions from $\mathrm{CO}_{2}$ capture to desulfurization, denitrofication and PM collection was well explored and best measures in practice given. Majority of the studies under consideration are consistent with their findings and agree with standard procedure. The results of this review serve as a platform to find benefits in reduction of pollution in the atmosphere thereby preventing acid rain. Furthermore, $\mathrm{CO}_{2}$ capture mitigates the critical issue of global warming and provision of good quality air could serve as a preventive measure against deadly respiratory diseases. More effort is, however, needed to improve bag-house PM collection system and eventual method of disposal.

\section{REFERENCES}


1. M. Asif and T. Muneer, "Energy supply, its demand and security issues for developed and emerging economies," Article in Press, Elsevier, 2005.

2. L. Remiorz, G. Wiciak and K. Grzywnowicz, "Novel concept of supporting the membrane separation of $\mathrm{CO}_{2}$ in Power plants by thermoacoustic dehumidification,” Energy, Elsevier, 189, 2019, https://doi.org/10.1016/j.energy.2019.116191

3. A. S. Sambo, "Renewable Energy for rural development: the nigerian perspective," ISESCO Science and Technology Vision, vol. 1, 2005.

4. J.M. Quimby and K.S. Kumar, "Hot gas cleanup for advanced power generation system," Springer, 1993, https://doi.org/10.1007/978-94-011-2172-9_6.

5. Coal Industry Advisory Board (CIAB), "Power generation from coal: measuring and reporting efficiency performance and $\mathrm{CO}_{2}$ emissions," OECD/IEA, Paris, 2010.

6. D.S.N. Prasad, R. Sharma, S. Acharya, M. Saxena and A. K. Sharma, "Removal of sulphur dioxide from flue gases in thermal plants," Rasayan Journal of Chemistry, vol. 3, No.2, 2010, pp. 328-334, http://www.rasayanjournal.com.

7. G. Singh, F. E. Koshky, F. Delijani, A. Moradian, M. N. Lakhoua, A. Y. Ryabchikov, J. Naser, A. H. Al-Abbas, S. Islam, I. Ullah and R. Mahamud, "Thermal power plants - advanced applications," InTech, Janeza Trdine, 9, 51000 Rijeka, Croatia, 2013.

8. Barclays Bank Plc, "Environmental and social risk briefing power generation,” Version 6.0, March 2015.

9. Y. S. H. Najjar, "Gaseous pollutants formation and their harmful effects on health and environment," Innovative Energy Policies, vol. 1, Ashdin Publishing, 2011.

10. K. T. Pickering and L. A. Owen, "An Introduction to Global Environmental Issues," Butler and Tanner Ltd, Frome and London, 1995.

11. B. Gottlieb, S. G. Gilbert and L. G. Evans, "Coal ash: the toxic threat to our health and environment," 2010.

12. D. B. Howard, J. The, R. Soria, N. Fann, R. Schaeffer and J. - D. M. Saphores, "Health benefits and control costs of tightening particulate matter emissions standards for coal power plants - the case of northeast brazil," Environment International, Elsevier, 124, 2019, pp. 420-430, https://doi.org/10.1016/j.envint.2019.01.029.

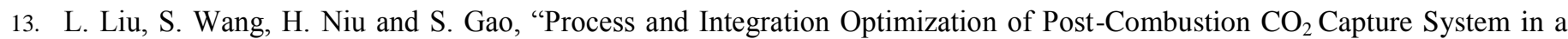
Coal Power Plant,” Energy Procedia, Elsevier, 154, 2018, pp. 86-93.

14. The International Council on Combustion Engines (CIMAC), "Guide to diesel exhaust emissions control of NOx, SOx, particulates, smoke and $\mathrm{CO}_{2}$ : seagoing ships and large stationary diesel power plants," 2008, http://www.cimac.com.

15. J. Mario, N. Nsakala, T. Griffin and A. Bill "Controlling power plant $\mathrm{CO}_{2}$ emissions: a long range view," ALSTOM Power Report, 2001.

16. R. Vinod and M. A. Reddy, "Zero emission power plant," IOSR Journal of Electrical and Electronics Engineering, vol. 2, Issue 4, September-October 2012, pp. 24-28, www.iosrjournals.org

17. P. Madejski, "Introductory chapter: new trends and recent developments for thermal power plants," 2018, http://dx.doi.org/10.5772/intechopen.74723.

18. C. Mborah and S. P. Agbomadzi, "Removal of carbon dioxide gas from the exhaust gases generated at the takoradi thermal power station," Research Journal of Environmental and Earth Sciences, Maxwell Scientific Organization, 2(4), 2010, Pp. 245-254.

19. I. Martínez, R. Murillo, G. Grasa, and J. C. Abanades, "Integration of a Ca looping system for $\mathrm{CO}_{2}$ capture in existing power plants," 2012.

20. Japan Coal Energy Center (JCOAL), "Clean coal technologies in Japan," Technological Innovation in the Coal Industry, January 2007.

21. H. Kikkawa, H. Ishizaka, K. Kai and T. Nakamoto "DeNOx, DeSOx and $\mathrm{CO}_{2}$ removal technology for power plant," Hitachi Review, vol. 57, No. 5, 2008, pp. 174-178.

22. S. Samanta and S. Ghosh, "Efficiency improvement and $\mathrm{CO}_{2}$ emission reduction of coal fired power plant by repowering through pressurized pulverized coal combustion and waste heated feed water heating," Journal of Power Technologies XX (X), 2011, X-X, http://www.papers.itc.pw.edu.pl. 
23. Ministry of Environment Japan, “Air pollution control technology in thermal power plants," A Contracted project-2004, 2005.

24. T. Kuroki, S. Nishii, T. Kuwahara and M. Okubo, "Nano-particle removal and exhaust gas cleaning using a gas-liquid interfacial non thermal plasma," Proceedings of Electrostatics Joint Conference, 2016.

25. N. Morgan, D. Ibrahim and A. Samir, "NO $\mathrm{X}$ emission reduction by non thermal plasma technique," Journal of Energy Environmental \& Chemical Engineering, 2(2), 2017, pp. 25-31, doi: 10.11648/j.jeece.20170202.12.

26. S. Ayub and S. K. Sharma, "Particulate matter emission from thermal power plant: parent material, formation mechanism, health concerns, control devices - a review," Global Journal of Engineering and Applied Sciences, vol. 1 (3), 2011, pp. 8792.

27. P. Rai, N. Gautam and H. Chandra, "Investigating Electrostatic Precipitator Design Parameters for Efficient Control of Particulate Matter in Thermal Power Plant: A Case Study" Journal of the Institution of Engineers India: Series A, 99(2), Springer, June 2018, pp. 303-310, https://doi.org/10.1007/s40030-018-0266-y.

28. H. Yi, J. Hao, L. Duan, X. Li and X. Guo, "Emission characteristics of fine particles from coal-fired power plants," Department of Environment Science and Engineering, Tsinghua University, Beijing, 100084, 2005.

29. A. Wang, Q. Song, G. Tu, H. Wang, Y. Yue, and Q. Yao, "Influence of flue gas cleaning system on characteristics of PM2.5 emission from coal-fired power plants," Journal of Coal Science and Technology, Springer-Verlag, 2014.

30. A. Bandyopadhyay and P. K. Mandal, "Investigation on multiple benefits of wet electrostatic precipitators for emission control in an Indian coal fired thermal power plant" Clean Technologies and Environmental Policy, Springer, 2015, 17, pp. 421-431, DOI 10.1007/s10098-014-0795-7. 